\title{
Determinants of job satisfaction: a European comparison of self-employed and paid employees
}

\author{
José María Millán • Jolanda Hessels • \\ Roy Thurik $\cdot$ Rafael Aguado
}

Accepted: 7 October 2011/Published online: 11 November 2011

(C) The Author(s) 2011. This article is published with open access at Springerlink.com

\begin{abstract}
The job satisfaction of self-employed and paid-employed workers is analyzed using the European Community Household Panel for the EU-15 covering the years 1994-2001. We distinguish between two types of job satisfaction: job satisfaction in terms of type of work and job satisfaction in terms of job security. Findings from our generalized ordered logit regressions indicate that self-employed individuals as compared to paid employees are more likely to be satisfied with their present jobs in terms of type of work and less likely to be satisfied in terms of job security. The findings also provide many insights into the determinants of the two types of job satisfaction for both self-employed and paid-employed workers.
\end{abstract}

Keywords Entrepreneurship - Self-employment . Job satisfaction · Europe

J. M. Millán · R. Aguado

Department of Economics, University of Huelva, Huelva, Spain

J. Hessels $(\bowtie) \cdot R$. Thurik

EIM Business and Policy Research, Zoetermeer,

The Netherlands

e-mail: joh@eim.nl

J. Hessels · R. Thurik

Erasmus School of Economics, Erasmus University

Rotterdam, Rotterdam, The Netherlands

R. Thurik

GSCM-Montpellier Business School, Montpellier, France
JEL Classifications $\quad \mathrm{J} 24 \cdot \mathrm{J} 28 \cdot \mathrm{L} 26 \cdot \mathrm{O} 52$

\section{Introduction}

Entrepreneurship as an occupational choice has been widely investigated. The choice between entrepreneurship (i.e., self-employment) and wage-employment is found to be influenced by a broad range of factors, including demographics, educational typology, labor market issues, and (expected) financial and (expected) non-financial benefits (Grilo and Thurik 2008; Parker 2009). Recent studies emphasize that job satisfaction may be an important determinant of the choice between self- and wage-employment (Blanchflower 2000, 2004; Georgellis et al. 2007; Taylor 1996, 1999).

A different body of research has identified various positive effects of job satisfaction on individual and organizational performance. For example, that there are quantifiable positive links between job satisfaction and organizational effectiveness (Koys 2001; Ostroff 1992) individual performance (Sousa-Poza and SousaPoza 2000), employee turnover (Ryan et al. 1996), customer satisfaction (Brown and Lam 2008; Rogers et al. 1994; Ryan et al. 1996), achievement orientation (Lusch and Serpkenci 1990), and lower absenteeism (Vroom 1964).

Therefore, job satisfaction is not only a determining factor of occupational choice, but may also contribute 
to a firm's competitiveness, productivity, and growth potential. Hence, it is important to investigate its determinants. This is not a new line of research. For many years labor economists have been interested in the determinants of job satisfaction (Blanchflower and Oswald 1998; Borjas 1979; Clark 1996; Clark and Oswald 1994; Freeman 1978; Hamermesh 1977; Meng 1990), while others have focused on job satisfaction in relation to self-employment (Benz and Frey 2004, 2008; Blanchflower 2000; Blanchflower and Oswald 1998; Hundley 2001; Noorderhaven et al. 2004). A consistent finding is that self-employed individuals tend to have higher levels of job satisfaction than employees.

Nevertheless, studies comparing job satisfaction between self-employed individuals and paid employees suffer from two shortcomings. First, similar to most studies explaining job satisfaction, they have failed to take into account that job satisfaction is a heterogeneous phenomenon. Self-reported job satisfaction may reflect satisfaction with both financial and non-financial benefits, and different people can mean different things when they evaluate the extent of their satisfaction with their job (Bianchi 2011; Muñoz de Bustillo-Llorente and Fernández-Macías 2005). For example, if one states to be satisfied with one's job, this may reflect satisfaction with its content or with the number of hours required to do the job or with both aspects. While some individuals may place a high or low value on some specific job-related aspects, which may influence their overall assessment of job satisfaction, for others it will comprise an evaluation of several different aspects. Therefore, it is difficult to assess what is actually measured when asking individuals to evaluate overall satisfaction with their jobs, which has in turn led to a lack of understanding of what job satisfaction refers to and how, ultimately, it can be influenced by employers and policy-makers. In the study reported here, we take an initial step in overcoming this problem by making a distinction between two types of job satisfaction, namely, job satisfaction with the type of work and job satisfaction with job security. Second, studies comparing job satisfaction between self-employed individuals and paid employed workers lack wide empirical coverage.

Simultaneously addressing these aspects of the existing literature is precisely the main aim of this work-that is, comparing self-reported levels of job satisfaction in terms of type of work and job security among self-employed individuals and paid employees by using survey data of 15 European countries for the 1994-2001 period and a large range of explanatory variables.

Since autonomy and independence are common motives for becoming self-employed, one would expect that self-employed workers have more freedom in determining their type of work and are therefore more likely than employees to be satisfied with their jobs as far as the type of work is concerned. However, with respect to job security, self-employment can be considered to be more risky than paid employment, as the risk of business failure can be expected to be higher than the risk of unemployment. Furthermore, selfemployment tends to be associated with lower levels of social security protection. Therefore, self-employed individuals are expected to be less satisfied than paid employees in terms of job security.

Next, by running separate estimations both for selfemployed individuals and employees, we also investigate the many determinants of job satisfaction in terms of the type of work and job security. This allows us to determine whether determinants of the two types of job satisfaction differ between self-employed individuals and paid employees.

The remainder of this paper is structured as follows. The literature background is dealt with in the section entitled Sect. 2. In this section we also develop two propositions. In the Sect. 3, we provide a description of our unique European dataset, i.e., the European Community Household Panel, the variables, and the methodology. The results are presented in the Sect. 4 section, and in the Sect. 5, we draw a number of conclusions and discuss the results in detail.

\section{Related literature}

Occupational choice refers to the choice to engage in self-employment or wage-employment (Evans and Jovanovic 1989; Kihlstrom and Laffont 1979). Many factors affect an individual's decision to become selfemployed (Grilo and Thurik 2008; Parker 2009). Next to demographic factors, educational attainment, and labor market experience, this decision may be influenced by financial considerations, such as expected income and profits and income variability, as well as non-financial considerations, such as autonomy, prestige, and job satisfaction (Acemoglu 1995; 
Van Praag 1999). Verheul et al. (2002) view occupational choice decisions as being made on the basis of an assessment of the potential risks and rewards of both employment options. Individuals compare both the (expected) financial and non-financial risks and rewards of the alternatives. In their assessment, individuals take into account environmental factors (opportunities and opportunity costs) as well as their individual characteristics (means, skills, and preferences).

Work may provide both economic and non-economic utility (Benz and Frey, 2008). Self-employment is often associated with lower levels of economic utility than wage employment (Hamilton 2000; Van Praag and Versloot 2007). The income of selfemployed workers also tends to be more variable than that of paid employees (Van Praag and Versloot 2007), which leads to the idea that the self-employed are able to obtain greater non-financial benefits than the wageemployed, such as greater independence or satisfaction (Bianchi 2011; Van Praag and Versloot 2007). One indicator of non-financial utility that has received considerable attention in previous studies is job satisfaction.

Job satisfaction broadly refers to the degree to which people like their work, and it is usually determined by self-reported information. As a rule, economists tend to avoid data based on subjective feelings such as job satisfaction. In addition, due to this subjective nature of job satisfaction and the problems involved in making interpersonal comparisons, it may be difficult for researchers to interpret responses to questions on job satisfaction. However, published studies that have investigated the relationship between satisfaction and self-employment have yielded consistent results across datasets, thereby providing confidence with respect to the reliability of the job satisfaction data in the economic literature on this subject (Blanchflower 2000; Blanchflower and Oswald 1998). Furthermore, there are several reasons why it is important to analyze a subjective indicator like job satisfaction. It is often argued that people who are satisfied with their work perform better (SousaPoza and Sousa-Poza 2000), and results from previous studies suggest both a direct and an indirect link between job satisfaction and organizational performance. For example, there is evidence of positive indirect linkages of satisfaction with organizational effectiveness (Koys 2001; Ostroff 1992) and employee turnover (Ryan et al. 1996). Indirect linkages of satisfaction with performance are suggested through a direct positive relationship between job satisfaction and customer satisfaction (Brown and Lam 2008; Rogers et al. 1994; Ryan et al. 1996), a positive link of satisfaction with achievement orientation (Lusch and Serpkenci 1990), and the observation that low satisfaction leads to higher absenteeism (Vroom 1964), job separations, and quits (Akerlof et al. 1988; Clark 2001; Clark et al. 1998). Thus, job satisfaction can be considered to be an important factor in improving a firm's competitiveness. Against this background we have witnessed an increased interest of economists in subjective aspects of well-being at work (Sousa-Poza and Sousa-Poza 2000).

Previous studies on job satisfaction have focused on analyzing various aspects of job satisfaction in relation to employees (Clark 1996, 1997; Clark and Oswald 1996; Sousa-Poza and Sousa-Poza 2000). Several studies have also included the self-employed in the analysis of job satisfaction. A consistent finding is that self-employed workers have higher levels of job satisfaction than employees (Bradley and Roberts 2004; Benz and Frey 2004, 2008; Blanchflower 2000; Blanchflower and Oswald 1998; Blanchflower et al. 2001; Parasuraman and Simmers 2001). In other words, individuals who are self-employed tend to be more satisfied with their jobs than individuals who work as employees. This is attributed in large part to the strong perception of independence of the selfemployed (Hyytinen and Ruuskanen 2006). It has been emphasized that job satisfaction is an important determinant of the choice between self- and wageemployment (Blanchflower 2000, 2004; Taylor 1996) and a strong predictor of self-employment exits (Georgellis et al. 2007). Job dissatisfaction has also been found to be a factor that pushes employees into self-employment because individuals who are dissatisfied with their jobs are more likely to seek alternatives to being paid employees (Brockhaus, 1980).

Job satisfaction may refer to financial and/or nonfinancial benefits, and different people can mean different things when they evaluate it. Previous studies have generally failed to consider the heterogeneity aspect of job satisfaction, although some have considered different job aspects, such as (satisfaction with) job security and type of work, as determinants of overall job satisfaction in comparing self-employed workers with employees (Benz and Frey 2008; Green 
and Tsitsianis 2005; Taylor 1996). Such work-related aspects are found to contribute to the overall job satisfaction of workers (Benz and Frey 2008; Green and Tsitsianis 2005). It has also been observed that people who place a high value on job security prefer paid employment over self-employment, while the reverse is true for people who are attracted to a certain occupation by the type of work (Taylor 1996). However, these studies provide no insight into the determinants of different types of job satisfaction. We are familiar with one study that analyzes some determinants of several types of job satisfaction among employees (Origo and Pagani 2009), but it does not include the self-employed and, therefore, it is not possible to compare the two groups of workers.

Precisely to fill this research gap, we have designed our study to distinguish between two types of job satisfaction, namely, with the type of work and with job security, and compare self-reported levels of these two types of job satisfaction among the self-employed and paid employees. Since being your own boss provides autonomy and independence, one would expect that the self-employed have more freedom in determining the type of work they do. This leads to our first proposition:

Proposition 1 The self-employed are more satisfied than paid employees with their present job in terms of type of work.

However, job security can be expected to be lower for the self-employed as compared to employees. The self-employed tend to have lower social security or employment protection (European Commission 2004). Also, the risk of failure is quite high for selfemployed individuals, particularly during the start-up phase. Approximately 50-60\% of new business startups survive the first 3 years of activity (Eurostat, 2004). The risk of business failure is much higher than the risk of becoming unemployed. Therefore, our second proposition is:

Proposition 2 The self-employed are less satisfied than paid employees with their present job in terms of job security.

The main objective of this paper is to test the validity of these propositions. In addition, we explore whether the two types of job satisfaction have different determinants by comparing the self-employed and employees. We will not make an a priori list of additional propositions given the large number of determinants we investigate.

\section{Data, methodology, and variables}

\subsection{Data source and sample}

\subsubsection{Data source}

We use data from the European Community Household Panel (ECHP) covering the period 1994-2001. ${ }^{1}$ The ECHP is a standardized multi-purpose annual longitudinal survey carried out at the level of the EU-15. ${ }^{2}$ It is designed and coordinated by the Statistical Office of the European Communities (Eurostat). The target population of the ECHP consists of people living in private households throughout the national territory of each country. The definition of household is based on the standard criteria of "sharing the same dwelling" and "common living arrangements". Individuals in the sample who move or join a new household are followed up at their new location. Lastly, the survey also covers all persons cohabiting with any of the original sample persons in the same household. These rules are followed to reflect the demographic changes in the population and to maintain the panels' cross-sectional representativeness of the population. ${ }^{3}$

Each year all members of the selected households in the participating countries are interviewed on issues relating to demographics, labor market characteristics, income, and living conditions. The same questionnaire is used in all countries; consequently, the information is directly comparable. The first wave of data collection was held in 1994. For the entire period 1994-2001, information on 60,500 nationally representative households, i.e., approximately 130,000 individuals aged 16 years and older, is available.

\footnotetext{
${ }^{1}$ ECHP data are used with the permission of Eurostat (contract ECHP/2006/09 with the Universidad de Huelva).

${ }^{2}$ Information concerning job satisfaction for Sweden was not collected.

${ }^{3}$ See Peracchi (2002) for a review of the organization of the survey, and a useful discussion of the issues a researcher may face when using these data.
} 


\subsubsection{Our sample}

To construct our sample, we first categorize individuals in the ECHP according to their labor market status, that is (1) paid employment, (2) self-employment, (3) education or training, (4) unemployment, (5) unpaid employment, and (6) inactivity. We next limit our sample to include only men and women aged 18-65 working either part-time or full-time in any business sector either as paid employees or selfemployed. ${ }^{4}$ Workers in the public sector are excluded from our analysis for comparability purposes between paid and self-employed individuals. ${ }^{5}$ In a final step, we remove observations with missing data for any of the variables included in our regressions. Our final dataset comprises 225,019 observations (62,652 individuals) with 59,604 (26.5\%) observations referring to selfemployment. Table 1 presents some of the descriptive information.

Table 1 reveals that the participation of females in the labor market is rather low, especially with respect to participation in self-employment, that selfemployed individuals are on average 7 years older than their paid counterparts, and that paid employees have received higher levels of education than selfemployed individuals. In terms of business sectors, our descriptive results show how self-employment is the natural employment status in the agricultural industries. Finally, on average, self-employed individuals work $10 \mathrm{~h}$ longer, earn $€ 1,900$ less, and show more income inequality (22.01 against 9.46 in terms of standard deviation for annual earnings) than paid employees.

\footnotetext{
$\overline{4}$ Individuals are forced to choose only one main occupation, either working for an employer in paid employment, or working as a self-employed. Since no information is collected on secondary activities, it is not possible to determine whether some individuals combine both self- and paid employment. When running our estimations, however, the exclusion of parttime workers (who might combine both activities) does not affect our results in any significant way. Therefore, our results seem to be robust to the presence of these special cases.

${ }^{5}$ We exclude workers in the public sector from the analysis because determinants of occupational choice and job satisfaction among public sector workers deviate from those of private sector workers. This difference is related to several factors, such as a relatively lower workload for public sector workers and a motivation to serve the community (Besley and Ghatak 2005; Delfgaauw and Dur 2008, 2009; Francois 2000; Glazer 2004; Prendergast 2007).
}

Reported levels of job satisfaction among selfemployed and paid employed individuals are presented in Table 2.

Table 2 shows that, on average, self-employed individuals report higher levels of satisfaction with the type of work and lower levels of satisfaction with job security than their paid-employee counterparts. These figures, however, do not hold for some countries. In France and Greece, for example, the percentage of respondents that report high job satisfaction with regard to the type of work is lower for the self-employed than for the paid-employed worker. Also, self-employed individuals in Denmark, Germany, Italy, and Portugal report having a high level of satisfaction with respect to job security more often than paid employees. ${ }^{6}$

\subsection{Methodology and dependent variables}

In this study, we use ordered logit models to investigate whether the self-employed are more satisfied or less satisfied with their job in terms of type of work and job security and to investigate the determinants of the two types of job satisfaction among the self-employed and employees. In particular, to avoid violation of the proportional odds assumption (also called parallel regressions assumption, or parallel lines assumption), we apply generalized ordered logit models. ${ }^{7}$

Within this framework, an individual's selfreported job satisfaction $\left(s a t_{I}\right)$ is interpreted as an ordinal indicator of a latent well-being variable $\left(W B_{I}\right)$, which is unobservable. Our dependent variables are job satisfaction in terms of type of work and job satisfaction in terms of job security. The value given these variables ranges from 1 to 6 , with 1 referring to individuals who are not satisfied with their present job and 6 referring to those who are completely satisfied

\footnotetext{
${ }^{6}$ The data in Table 2 indicate that it is questionable to assume uniform results across the sample of countries. Thus, in order to test if the fit is similar across all countries (or if the results are being skewed by some idiosyncratic specifications for a few countries), we ran separate estimations country by country; the results of these robustness tests are reported in Sect. 4.

7 The parallel lines model is a special case of the generalized ordered model which assumes that the coefficients are equal across categories (proportional-odds assumption-also called parallel lines assumption). Different tests provided evidence that the parallel regression assumption was violated and, as a consequence, demonstrate the need to apply generalized ordered logit models. See Williams (2006) for a complete description of the methodology.
} 
Table 1 Descriptive statistics

\begin{tabular}{|c|c|c|c|}
\hline Group & All workers & Paid employees & Self-employed \\
\hline Number of observations & 225,059 & 165,455 & 59,604 \\
\hline Number of individuals & 62,652 & 48,983 & 17,363 \\
\hline \multicolumn{4}{|l|}{ Job satisfaction (JS) with type of work } \\
\hline JS with type of work $=1$ & $7.49 \%$ & $7.14 \%$ & $8.46 \%$ \\
\hline JS with type of work $=2$ & $40.17 \%$ & $39.97 \%$ & $40.75 \%$ \\
\hline JS with type of work $=3$ & $52.34 \%$ & $52.89 \%$ & $50.79 \%$ \\
\hline \multicolumn{4}{|l|}{ Job satisfaction (JS) with job security } \\
\hline JS with job security $=1$ & $13.43 \%$ & $12.67 \%$ & $15.54 \%$ \\
\hline JS with job security $=2$ & $41.87 \%$ & $40.73 \%$ & $45.04 \%$ \\
\hline JS with job security $=3$ & $44.70 \%$ & $46.61 \%$ & $39.42 \%$ \\
\hline \multicolumn{4}{|l|}{ Demographic characteristics } \\
\hline Female & $34.89 \%$ & $37.6 \%$ & $27.39 \%$ \\
\hline Age (18-65 years) & $39.05(11.25)$ & $37.23(10.78)$ & 44.09 (10.99) \\
\hline Cohabiting & $73.45 \%$ & $70.54 \%$ & $81.52 \%$ \\
\hline Children aged $<14$ years & $0.62(0.9)$ & $0.61(0.89)$ & $0.63(0.93)$ \\
\hline \multicolumn{4}{|l|}{ Education } \\
\hline No education or primary education & $49.25 \%$ & $46.34 \%$ & $57.35 \%$ \\
\hline Secondary education & $35.07 \%$ & $37.51 \%$ & $28.3 \%$ \\
\hline University studies & $15.68 \%$ & $16.16 \%$ & $14.35 \%$ \\
\hline \multicolumn{4}{|l|}{ Employment characteristics } \\
\hline Agricultural sector & $10.17 \%$ & $3.2 \%$ & $29.5 \%$ \\
\hline Industrial sector & $26.86 \%$ & $32.64 \%$ & $10.8 \%$ \\
\hline Construction sector & $11.02 \%$ & $11.12 \%$ & $10.76 \%$ \\
\hline Services sector & $51.95 \%$ & $53.03 \%$ & $48.94 \%$ \\
\hline No employees & & & $52.51 \%$ \\
\hline Micro firm (1-4 employees) & & $17.57 \%$ & $35.96 \%$ \\
\hline Small firm (5-19 employees) & & $42.01 \%$ & $10.2 \%$ \\
\hline Medium-sized firm (20-99 employees) & & $10.41 \%$ & $0.59 \%$ \\
\hline Large firm (>99 employees) & & $30.01 \%$ & $0.74 \%$ \\
\hline Hours of work & $42.63(11.88)$ & $39.89(8.92)$ & $50.26(15.27)$ \\
\hline Indefinite contract & & $82.8 \%$ & \\
\hline Intermediate & & $14.45 \%$ & \\
\hline Supervisory & & $10.76 \%$ & \\
\hline Recent spell(s) as unemployed & $35.23 \%$ & $40.26 \%$ & $21.28 \%$ \\
\hline Considers herself better skilled & $50.69 \%$ & $53.79 \%$ & $42.1 \%$ \\
\hline \multicolumn{4}{|l|}{ Incomes } \\
\hline Income situation (1-5) & $2.95(0.86)$ & $3(0.86)$ & $2.82(0.84)$ \\
\hline Ends meet (1-6) & $3.44(1.21)$ & $3.49(1.21)$ & $3.29(1.18)$ \\
\hline Annual earnings $t-1\left({ }^{`} 000\right)$ & $12.2(13.96)$ & $12.69(9.46)$ & $10.82(22.01)$ \\
\hline \multicolumn{4}{|l|}{ Country } \\
\hline Austria & $6.88 \%$ & $7.54 \%$ & $5.02 \%$ \\
\hline Belgium & $3.83 \%$ & $4.34 \%$ & $2.41 \%$ \\
\hline Denmark & $4.61 \%$ & $5.51 \%$ & $2.11 \%$ \\
\hline Finland & $4.63 \%$ & $4.38 \%$ & $5.31 \%$ \\
\hline France & $5.94 \%$ & $7.5 \%$ & $1.58 \%$ \\
\hline
\end{tabular}


Table 1 continued

\begin{tabular}{lccc}
\hline Group & All workers & Paid employees & Self-employed \\
\hline Germany & $3.54 \%$ & $4.27 \%$ & $1.51 \%$ \\
Greece & $10.53 \%$ & $6.77 \%$ & $20.98 \%$ \\
Ireland & $5.75 \%$ & $5.52 \%$ & $6.38 \%$ \\
Italy & $14.44 \%$ & $12.73 \%$ & $19.19 \%$ \\
Luxembourg & $0.86 \%$ & $1 \%$ & $0.47 \%$ \\
Netherlands & $8.57 \%$ & $10.88 \%$ & $2.16 \%$ \\
Portugal & $14.17 \%$ & $13.59 \%$ & $15.78 \%$ \\
Spain & $14.58 \%$ & $14.52 \%$ & $14.76 \%$ \\
United Kingdom & $1.67 \%$ & $1.43 \%$ & $2.33 \%$ \\
\hline
\end{tabular}

Standard deviations for continuous explanatory variables are given in parentheses

Three values were given for job satisfaction: 1, dissatisfied; 2 neither dissatisfied nor satisfied; 3 , satisfied

with their job. The dependent variable has been reclassified into three values for job satisfaction: (1) dissatisfied, (2) neither dissatisfied nor satisfied, and (3) satisfied. ${ }^{8}$ The relationship between self-reported job satisfaction $\left(s a t_{I}\right)$ and the latent variable $\left(W B_{I}\right)$ is given by

$\begin{array}{lll}s a t_{I}=1 & \text { if } & -\infty<W B_{I} \leq \mu_{1} \\ s a t_{I}=2 & \text { if } & \mu_{1}<W B_{I} \leq \mu_{2} \\ \text { sat }_{I}=3 & \text { if } & \mu_{2}<W B_{I} \leq+\infty\end{array}$

where $\mu_{1}$ and $\mu_{2}$ are the thresholds of the variable $W B_{I}$ that divide its range into separate intervals associated with the different levels of job satisfaction.

The generalized ordered logit model can be written as

$\operatorname{Pr}\left(\right.$ sat $\left._{I}>j\right)=g\left(X \beta_{j}\right)=\frac{\exp \left(a_{j}+X_{I} \beta_{j}\right)}{1+\exp \left(a_{j}+X_{I} \beta_{j}\right)}$

where the vector $X_{I}$ represents individual and firmspecific characteristics and economic conditions; $\beta_{j}$ is the associated vector of coefficients to be estimated ${ }^{9}$;

\footnotetext{
8 There are two reasons for choosing this procedure: first, in most cases, there are only a few observations in the low satisfaction scales. A second reason is that we assume that there is quite a bit of "noise" in detailed scales. This can be illustrated using the following-much-cited-example: people usually know if they are tall or short; they may, however, have difficulties in classifying themselves as very short or extremely short.

9 The formulas for the parallel lines model and generalized ordered logit model are the same, except that in the parallel lines model the betas (but not the alphas) are the same for all values of $j$.
}

$g(\cdot)$ is specified as the logistic cumulative distribution function. It can be determined that the probabilities that $s a t_{I}$ will take on each of the values $1-3$ is equal to

$$
\begin{aligned}
& \operatorname{Pr}\left(\text { sat }_{I}=1\right)=1-g\left(X_{I} \beta_{1}\right) \\
& \operatorname{Pr}\left(\text { sat }_{I}=2\right)=g\left(X_{I} \beta_{1}\right)-g\left(X_{I} \beta_{2}\right) \\
& \operatorname{Pr}\left(\text { sat }_{I}=3\right)=g\left(X_{I} \beta_{2}\right)
\end{aligned}
$$

We will first explore the determinants of job satisfaction on the full sample of workers as this will allow us to test whether there are significant differences on reported job satisfaction levels between self-employed and paid-employed workers (by including a selfemployed dummy). In addition, to explore whether the determinants of job satisfaction differ for the selfemployed and employees, separate estimations are conducted for both groups of workers. Since the ECHP tracks the same individuals from 1994 to 2001, standard errors are adjusted for intra-individual correlation to control for possible unobserved heterogeneity.

\subsection{Independent variables}

\subsubsection{Propositions related to the independent variable}

The individuals in our dataset provided detailed information on their main activity status. Based on this self-reported information, we construct our main independent variable, namely, self-employed: a dummy taking the value 1 for those being self-employed and taking the value 0 for those being wage-employed. 
Table 2 Percentage of observations reporting high satisfaction levels (Job satisfaction is high: JS = 3)

\begin{tabular}{|c|c|c|c|c|c|c|}
\hline \multirow[t]{3}{*}{ Country } & \multicolumn{6}{|c|}{ Job satisfaction with: } \\
\hline & \multicolumn{3}{|l|}{ Type of work } & \multicolumn{3}{|l|}{ Job security } \\
\hline & $\begin{array}{l}\text { All workers } \\
(\%)\end{array}$ & $\begin{array}{l}\text { Paid employees } \\
\text { (\%) }\end{array}$ & $\begin{array}{l}\text { Self-employed } \\
(\%)\end{array}$ & $\begin{array}{l}\text { All workers } \\
(\%)\end{array}$ & $\begin{array}{l}\text { Paid employees } \\
(\%)\end{array}$ & $\begin{array}{l}\text { Self-employed } \\
(\%)\end{array}$ \\
\hline Austria & 77.67 & 77.08 & 80.11 & 67.94 & 68.05 & 67.45 \\
\hline Belgium & 62.03 & 59.94 & 72.48 & 53.12 & 54.12 & 48.16 \\
\hline Denmark & 71.75 & 70.01 & 84.39 & 65.95 & 65.71 & 67.68 \\
\hline Finland & 54.5 & 52.21 & 59.75 & 53.11 & 56.4 & 45.56 \\
\hline France & 62.77 & 62.96 & 60.28 & 40.69 & 41.14 & 34.75 \\
\hline Germany & 59.74 & 57.39 & 78.25 & 48.06 & 47.62 & 51.5 \\
\hline Greece & 27.71 & 28.59 & 26.92 & 24.67 & 25.16 & 24.22 \\
\hline Ireland & 70.14 & 65.87 & 80.39 & 59.6 & 60.53 & 57.37 \\
\hline Italy & 45.94 & 41.96 & 53.28 & 38.53 & 36.6 & 42.07 \\
\hline Luxembourg & 70.03 & 67.87 & 82.86 & 63.8 & 65.22 & 55.36 \\
\hline Netherlands & 71.54 & 70.47 & 86.51 & 64.6 & 65.11 & 57.52 \\
\hline Portugal & 30.08 & 29.56 & 31.32 & 23.88 & 23.09 & 25.76 \\
\hline Spain & 50.48 & 48.65 & 55.46 & 45.07 & 45.9 & 42.81 \\
\hline United Kingdom & 60.21 & 56.78 & 66.07 & 44.97 & 46.39 & 42.56 \\
\hline Unweighted average & 58.19 & 56.38 & 65.58 & 49.57 & 50.08 & 47.34 \\
\hline
\end{tabular}

\subsubsection{Control variables}

Despite being relative latecomers to the job satisfaction field (compared to psychologists or sociologists), economists, when explaining job satisfaction, use similar explanatory variables to those included in earning equations. In the analyses we include a large number of individual-specific independent variables, such as demographic indicators (gender and age), family aspects and structure (cohabiting status and number of young children), educational attainment, firm-specific indicators (firm size and sector of industry), and employment characteristics (job status, type of contract, hours of work, past spells of unemployment, and a control that captures the degree that individuals think they have the skills or qualifications to do a more demanding job than they currently do). Finally, we also explore the impact of several income characteristics on job satisfaction (level of earnings, relative earnings compared to last year's level, easiness to make ends meet). Earnings are corrected by purchasing power parities (comparability across countries), and harmonized consumer price indexes are used (comparability across time). Harmonized national unemployment rates from the Organization for Economic Co-operation and Development
(OECD) are also included to capture the state of the various national economies in the period under study. ${ }^{10}$ A detailed definition of our variables is presented in Table 5.

\section{Results}

The main results of the empirical analyses are presented in this section. They are not directly comparable to those reported in earlier studies for two reasons. First, the existing literature on selfemployment is scarce; second, and more importantly,

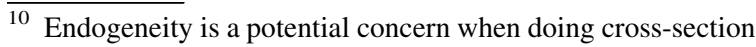
analysis. The reason why we did not include any time lag between our main independent variable (self-employment dummy) and our dependent variables (job satisfaction) is that it can be expected that the current employment position determines the assessment of job satisfaction. Also, while we cannot rule out the possibility that the observed empirical correlation between job satisfaction and self-employment is due to some other effect, we included a large number of potential explanatory variables to reduce potential omitted variable bias. With respect to multicollinearity, the maximum correlation between variables is 0.39 (between hours of work and selfemployed), and variance inflations factors range from 1.07 to 3.03. Therefore, multicollinearity is not a concern.
} 
previous results refer to a global measure of job satisfaction which is not directly comparable with our two different measures capturing separate aspects of job satisfaction (type of work and job security). For this reason we will simply describe our results.

First, the results for the estimates of the probability of being satisfied with a present job in terms of the type of work for all workers (both self-employed and employees) as well as for self-employed individuals and employees separately are presented in Table 3 and discussed in subsection 4.1. Subsequently, in subsection 4.2, we discuss the results of the predicted probabilities for both groups of workers using satisfaction with a present job in terms of job security as the dependent variable. The results for these estimates are presented in Table 4. In a three-column format, both Tables 3 and 4 present the results for all workers (both self-employed and employees) in the first column and for the paidemployed and self-employed workers separately (in the second and third columns, respectively). At the top of each column, the number of individuals and observations involved in the estimations are reported. Then, the predicted probabilities of job satisfaction for the sample means are shown for each possible level of job satisfaction $(1=$ dissatisfied, $2=$ neither dissatisfied nor satisfied, $3=$ satisfied). Below these probabilities, only the effects of the explanatory variables on the probability that individuals are satisfied with their job (job satisfaction equals 3) are presented in terms of marginal effects (and not the coefficients). These marginal effects are expressed in relative terms (with respect to the predicted probabilities for the sample means). Finally, $t$ statistics associated with marginal effects are reported in each column.

\subsection{Satisfaction with present job in terms of type of work}

The first column in Table 3 presents results for satisfaction with the present job in terms of the type of work as the dependent variable, including all workers (both self-employed individuals and employees). In accordance with proposition 1, the selfemployment dummy reveals that the self-employed are more satisfied with their jobs in terms of type of work than employees. ${ }^{11}$ To be precise, we observe a

\footnotetext{
11 When running these estimations country by country as robustness tests, the same results persist for all countries except
}

$14 \%$ increase in the probability of being satisfied with the type of work in the case of being self-employed. The magnitude of this marginal effect justifies a separate analysis for self-employed individuals and employees, which is presented in the second and third columns of Table 3 . We will now present results that follow from these two columns.

With respect to demographic characteristics, a number of factors, such as gender and cohabitation status, do not affect the level of job satisfaction for either paid-employed or self-employed workers. Furthermore, the findings indicate that for both groups of workers, the relationship between age and the probability of being satisfied seems to be non-linear, showing a U-shaped pattern which reaches the lower probability at the age of 40 years for employees and 46 years for the self-employed.

In terms of education, the findings indicate that education matters among both groups of workers in the sense that those who received secondary schooling or university education are more likely to be satisfied with their type of work than those who received only primary education or no schooling at all. This effect is especially relevant in the case of self-employed individuals. For self-employed individuals with a university education, the predicted probability of being satisfied with the type of work increases by approximately $33 \%$, while the increase amounts to only $9 \%$ for employees.

Several employment characteristics are considered. For both groups of workers, those working in agriculture are less likely to be satisfied with their type of work (in comparison to individuals working in other industries). This effect is stronger for self-employed individuals than for employees. Regarding firm size, we find that those employees working in micro, small, and medium-sized firms are more likely to be satisfied with their type of work than those working in large firms (>99 employees). For self-employed individuals, however, being a self-employed individual without employees marginally reduces the likelihood of being satisfied, compared with those who hire employees. Furthermore, employees having a supervisory or an

\footnotetext{
Footnote 11 continued

for France, Greece, and the UK where being self-employed (as opposed to being paid employed) does not seem to alter the likelihood of being satisfied with the type of work. These additional estimations are not reported for brevity and are available upon request.
} 
Table 3 Job satisfaction with type of work -generalized ordered logit estimations

\begin{tabular}{|c|c|c|c|c|c|c|}
\hline Group & \multicolumn{2}{|c|}{ All workers } & \multicolumn{2}{|c|}{ Paid employed } & \multicolumn{2}{|c|}{ Self-employed } \\
\hline Total no. of individuals & \multicolumn{2}{|c|}{62,652} & \multicolumn{2}{|c|}{48,983} & \multicolumn{2}{|c|}{17,363} \\
\hline Total number of observations & \multicolumn{2}{|c|}{225,059} & \multicolumn{2}{|c|}{165,455} & \multicolumn{2}{|c|}{59,604} \\
\hline $\operatorname{Prob}(\mathrm{JS}=1)$ & \multicolumn{2}{|c|}{0.0536} & \multicolumn{2}{|c|}{0.0503} & \multicolumn{2}{|c|}{0.0549} \\
\hline $\operatorname{Prob}(\mathrm{JS}=2)$ & \multicolumn{2}{|c|}{0.4196} & \multicolumn{2}{|c|}{0.4159} & \multicolumn{2}{|c|}{0.4318} \\
\hline Prob $(\mathrm{JS}=3)$ & \multicolumn{2}{|c|}{0.5268} & \multicolumn{2}{|c|}{0.5338} & \multicolumn{2}{|c|}{$\mathbf{0 . 5 1 3 2}$} \\
\hline Variables & $\begin{array}{l}\text { Marginal } \\
\text { effects }(\%)\end{array}$ & $t$ statistics & $\begin{array}{l}\text { Marginal } \\
\text { effects }(\%)\end{array}$ & $t$ statistics & $\begin{array}{l}\text { Marginal } \\
\text { effects }(\%)\end{array}$ & $t$ statistics \\
\hline Self-employed ${ }^{\text {a }}$ & $14.15 \%$ & $16.63 * * *$ & & & & \\
\hline \multicolumn{7}{|l|}{ Demographic characteristics } \\
\hline Female & $-1.51 \%$ & $-2.07 * *$ & $-0.17 \%$ & -0.21 & $-1.8 \%$ & -1.19 \\
\hline Age (18-65 years) & $-0.02 \%$ & -0.09 & $-1.05 \%$ & $-4.32 * * *$ & $-1.19 \%$ & $-2.74 * * *$ \\
\hline Age (squared) & $0.0009 \%$ & 0.39 & $0.0134 \%$ & $4.38 * * *$ & $0.0131 \%$ & $2.68 * * *$ \\
\hline Cohabiting $^{\mathrm{b}}$ & $-0.66 \%$ & -0.84 & $-0.81 \%$ & -0.93 & $-2.44 \%$ & -1.39 \\
\hline Children ages $<14$ years & $0.65 \%$ & $1.75^{*}$ & $0.7 \%$ & $1.66^{*}$ & $-0.65 \%$ & -0.86 \\
\hline \multicolumn{7}{|l|}{ Education } \\
\hline Secondary education $^{c}$ & $11.09 \%$ & $15.86 * * *$ & $7.01 \%$ & $8.93 * * *$ & $15.02 \%$ & $9.9 * * *$ \\
\hline University studies $^{\mathrm{c}}$ & $18.74 \%$ & $19.98 * * *$ & $9.3 \%$ & $8.62 * * *$ & $32.52 \%$ & $16.35 * * *$ \\
\hline \multicolumn{7}{|l|}{ Employment characteristics } \\
\hline Agricultural sector ${ }^{\mathrm{d}}$ & $-18.35 \%$ & $-12.96 * * *$ & $-4.83 \%$ & $-2.2 * *$ & $-22.95 \%$ & $-9.82 * * *$ \\
\hline Industrial sector ${ }^{\mathrm{d}}$ & $1.72 \%$ & 1.61 & $1.28 \%$ & 1.07 & $14.64 \%$ & $5.69 * * *$ \\
\hline Services sector ${ }^{\mathrm{d}}$ & $8.09 \%$ & $7.97 * * *$ & $8.08 \%$ & $6.94 * * *$ & $5.44 \%$ & $2.63 * * *$ \\
\hline No employees ${ }^{\mathrm{e}}$ & & & & & $-3.38 \%$ & -1.63 \\
\hline Micro firm (1-4 employees) ${ }^{\mathrm{e}}$ & & & $8.31 \%$ & $7.78 * * *$ & $0.07 \%$ & 0.04 \\
\hline Small firm (5-19 employees) $)^{\mathrm{e}}$ & & & $6.35 \%$ & $7.3 * * *$ & & \\
\hline Medium-sized firm (20-99 employees) ${ }^{\mathrm{e}}$ & & & $2.92 \%$ & $2.54 * *$ & & \\
\hline Intermediate $^{\mathrm{f}}$ & & & $16.93 \%$ & $19.33 * * *$ & & \\
\hline Supervisory $^{\mathrm{f}}$ & & & $27.11 \%$ & $24.18 * * *$ & & \\
\hline Indefinite contract & & & $14.17 \%$ & $16.35 * * *$ & & \\
\hline Hours of work & $0.2 \%$ & $1.95 *$ & $-0.45 \%$ & $-3.07 * * *$ & $0.87 \%$ & $4.89 * * *$ \\
\hline Hours of work (squared) & $0.0009 \%$ & 0.88 & $0.0055 \%$ & $3.28 * * *$ & $-0.0048 \%$ & $-2.97 * * *$ \\
\hline Recent spell(s) as unemployed & $-8.23 \%$ & $-11.71 * * *$ & $-6.26 \%$ & $-8.02 * * *$ & $-9.37 \%$ & $-5.87 * * *$ \\
\hline Considers herself better skilled & $-9.96 \%$ & $-17.35 * * *$ & $-13.5 \%$ & $-20.67 * * *$ & $-1.03 \%$ & -0.87 \\
\hline \multicolumn{7}{|l|}{ Incomes } \\
\hline Income situation (1-5) & $3.79 \%$ & $12.52 * * *$ & $3.95 \%$ & $11.58 * * *$ & $3.55 \%$ & $5.52 * * *$ \\
\hline Ends meet (1-6) & $8.11 \%$ & $28.82 * * *$ & $6.5 \%$ & $20.33 * * *$ & $10.77 \%$ & $18.62 * * *$ \\
\hline Annual earnings $t-1\left({ }^{`} 000\right)$ & $0.56 \%$ & $13.97 * * *$ & $0.53 \%$ & $8.75^{* * *}$ & $0.29 \%$ & $5.52 * * *$ \\
\hline \multicolumn{7}{|l|}{ Business cycle } \\
\hline Unemployment rate $(\%)$ & $0.76 \%$ & $6.03 * * *$ & $0.66 \%$ & $4.52 * * *$ & $1.1 \%$ & $4.24 * * *$ \\
\hline \multicolumn{7}{|l|}{ Country } \\
\hline Austria $^{\mathrm{g}}$ & $55.6 \%$ & $38.92 * * *$ & $49.4 \%$ & $29.4 * * *$ & $65.37 \%$ & $21.92 * * *$ \\
\hline Belgium $^{\mathrm{g}}$ & $12.66 \%$ & $6.89 * * *$ & $8.77 \%$ & $4.34 * * *$ & $19.18 \%$ & $4.26^{* * *}$ \\
\hline Denmark $^{\mathrm{g}}$ & $36.18 \%$ & $20.24 * * *$ & $30.38 \%$ & $15.25 * * *$ & $61.06 \%$ & $14.75^{* * *}$ \\
\hline Finland $^{\mathrm{g}}$ & $2.68 \%$ & $1.75^{*}$ & $-3.21 \%$ & $-1.82 *$ & $11.36 \%$ & $3.58 * * *$ \\
\hline France $^{\mathrm{g}}$ & $22.68 \%$ & $15.47 * * *$ & $18.92 \%$ & $12.01 * * *$ & $3.9 \%$ & 0.95 \\
\hline
\end{tabular}


Table 3 continued

\begin{tabular}{|c|c|c|c|c|c|c|}
\hline Variables & $\begin{array}{l}\text { Marginal } \\
\text { effects }(\%)\end{array}$ & $t$ statistics & $\begin{array}{l}\text { Marginal } \\
\text { effects }(\%)\end{array}$ & $t$ statistics & $\begin{array}{l}\text { Marginal } \\
\text { effects }(\%)\end{array}$ & $t$ statistics \\
\hline Germany $^{\mathrm{g}}$ & $9.91 \%$ & $5.68 * * *$ & $5.92 \%$ & $3.13 * * *$ & $27.23 \%$ & $5.5 * * *$ \\
\hline Greece $^{\mathrm{g}}$ & $-41.83 \%$ & $-32.43 * * *$ & $-33.7 \%$ & $-20.11 * * *$ & $-48.35 \%$ & $-20.93^{* * *}$ \\
\hline Ireland $^{\mathrm{g}}$ & $36.48 \%$ & $25.46 * * *$ & $25.9 \%$ & $15.01 * * *$ & $59.07 \%$ & $22.83 * * *$ \\
\hline Italy $^{\mathrm{g}}$ & $-9.39 \%$ & $-7.48 * * *$ & $-16.43 \%$ & $-11.29 * * *$ & $-5.37 \%$ & $-2.15^{* *}$ \\
\hline Luxembourg $^{\mathrm{g}}$ & $29.69 \%$ & $9.55 * * *$ & $22.68 \%$ & $6.59 * * *$ & $51.1 \%$ & $6.87 * * *$ \\
\hline Netherlands ${ }^{\mathrm{g}}$ & $36.8 \%$ & $22.52 * * *$ & $30.1 \%$ & $16.19 * * *$ & $69.22 \%$ & $22.83 * * *$ \\
\hline Portugal $^{\mathrm{g}}$ & $-25.17 \%$ & $-15.02 * * *$ & $-28.25 \%$ & $-14.9 * * *$ & $-24 \%$ & $-6.94 * * *$ \\
\hline United Kingdom ${ }^{\mathrm{g}}$ & $13.66 \%$ & $6.56 * * *$ & $9.01 \%$ & $3.82 * * *$ & $15.43 \%$ & $3.52 * * *$ \\
\hline Log pseudolikelihood & \multicolumn{2}{|c|}{$-181,885.5$} & \multicolumn{2}{|c|}{$-132,918$} & \multicolumn{2}{|c|}{$-47,032.1$} \\
\hline
\end{tabular}

* Significant at $10 \%$ level, $* *$ significant at $5 \%$ level, *** significant at $1 \%$ level

Reference category: ${ }^{\mathrm{a}}$ paid employed; ${ }^{\mathrm{b}}$ non-cohabiting individuals; ${ }^{\mathrm{c}}$ no education or primary education; ${ }^{\mathrm{d}}$ construction sector; ${ }^{\mathrm{e}}$ for paid employees, the reference category is large firm ( $>99$ employees); for self-employed the reference category is small, mediumsized, and large firms ( $>4$ employees); ${ }^{\mathrm{f}}$ non-supervisory; ${ }^{\mathrm{g}}$ Spain

For brevity and focus, only the effects of the explanatory variables on the probability that individuals are satisfied with their job (job satisfaction equals 3) are presented in bold

intermediate job status (as compared to having a nonsupervisory role) are more likely to be satisfied. Employees with indefinite contracts are also more likely to be satisfied in terms of type of work. When employees work longer hours, there is a negative (nonlinear) association with satisfaction with the type of work. Conversely, when self-employed individuals work longer hours, this results in a positive (non-linear) association with satisfaction with the type of work. It appears that a recent unemployment (after 1989) experience decreases satisfaction with the type of work for all workers (both employees and the selfemployed). Furthermore, those employees who think they have the skills or qualifications to do a more demanding job than they currently do are less likely to be satisfied with the type of work. The same does not hold true, however, for self-employed individuals.

We also explored the impact of several income characteristics on job satisfaction. For both employees and the self-employed, having higher relatively earnings compared to last year, coming from households that more easily make ends meet, and having a higher work incomes increases the likelihood of being satisfied with the type of work.

In terms of the impact of the state of the various national economies, it can be seen that when countries have higher unemployment rates, both employees and self-employed individuals are more likely to be satisfied with the type of work they do.
Finally, we also included country dummies using Spain as the reference category. There are hardly any differences between the results for employees and the self-employed. A general observation is that workers from Austria, The Netherlands, Ireland, Denmark, and Luxembourg are more likely to report high levels of satisfaction with the type of work than those from other countries within the EU-15. The reverse is true for workers from Greece, Portugal, and Italy.

\subsection{Satisfaction with present job in terms of job security}

As explained above, we focus not only on job satisfaction in terms of type of work but also on satisfaction in terms of job security. Table 4 shows the results for satisfaction with the present job in terms of job security as the dependent variable. In line with our second proposition, we find that the self-employed are less likely to be satisfied with their present job in terms of job security than paid employees. ${ }^{12}$ Our results show that

\footnotetext{
$\overline{12}$ The same analysis was performed country by country as a robustness test. The only deviation from the norm concerns Italian paid employees, which present lower levels of satisfaction with job security than their self-employed counterparts. In addition, our results do not reveal any effect of being self-employed (as opposed to being paid employed) on the likelihood of being satisfied with job security for Denmark, Germany, Portugal, and the UK. These additional estimations are available upon request.
} 
Table 4 Job satisfaction with job security -generalized Ordered Logit estimations

\begin{tabular}{|c|c|c|c|c|c|c|}
\hline Group & \multicolumn{2}{|c|}{ All workers } & \multicolumn{2}{|c|}{ Paid employed } & \multicolumn{2}{|c|}{ Self-employed } \\
\hline Total no. of individuals & \multicolumn{2}{|l|}{62,652} & \multicolumn{2}{|c|}{48,983} & \multicolumn{2}{|c|}{17,363} \\
\hline Total number of observations & \multicolumn{2}{|l|}{225,059} & \multicolumn{2}{|c|}{165,455} & \multicolumn{2}{|c|}{59,604} \\
\hline Prob (JS = 1) & \multicolumn{2}{|l|}{0.1087} & \multicolumn{2}{|c|}{0.922} & \multicolumn{2}{|c|}{0.1278} \\
\hline Prob (JS = 2) & \multicolumn{2}{|l|}{0.4516} & \multicolumn{2}{|c|}{0.4546} & \multicolumn{2}{|c|}{0.4922} \\
\hline Prob (JS = 3) & \multicolumn{2}{|l|}{0.4397} & \multicolumn{2}{|c|}{0.4532} & \multicolumn{2}{|c|}{0.38} \\
\hline Variables & $\begin{array}{l}\text { Marginal } \\
\text { effects }(\%)\end{array}$ & $t$ statistics & $\begin{array}{l}\text { Marginal } \\
\text { effects }(\%)\end{array}$ & $t$ statistics & $\begin{array}{l}\text { Marginal } \\
\text { effects }(\%)\end{array}$ & $t$ statistics \\
\hline Self-employed ${ }^{\mathrm{a}}$ & $-9.02 \%$ & $-9.1 * * *$ & & & & \\
\hline \multicolumn{7}{|l|}{ Demographic characteristics } \\
\hline Female & $6.46 \%$ & $7.38 * * *$ & $6.39 \%$ & $6.42 * * *$ & $8.16 \%$ & $4.5^{* * *}$ \\
\hline Age (18-65 years) & $-2.16 \%$ & $-9.13 * * *$ & $-4.45 \%$ & $-15.48 * * *$ & $-3.11 \%$ & $-5.89 * * *$ \\
\hline Age (squared) & $0.0263 \%$ & $9.14 * * *$ & $0.0525 \%$ & $14.57 * * *$ & $0.0354 \%$ & $5.99 * * *$ \\
\hline Cohabiting $^{\mathrm{b}}$ & $2.89 \%$ & $3.25 * * *$ & $1.95 \%$ & $1.85^{*}$ & $0.01 \%$ & 0.01 \\
\hline Children under 14 & $0.5 \%$ & 1.19 & $0.41 \%$ & 0.85 & $0.21 \%$ & 0.24 \\
\hline \multicolumn{7}{|l|}{ Education } \\
\hline Secondary education $^{c}$ & $1.84 \%$ & $2.28 * *$ & $-1.41 \%$ & -1.57 & $-2.11 \%$ & -1.16 \\
\hline University studies $^{\mathrm{d}}$ & $0.45 \%$ & 0.4 & $-5.6 \%$ & $-4.62 * * *$ & $-0.97 \%$ & -0.39 \\
\hline \multicolumn{7}{|l|}{ Employment characteristics } \\
\hline Agricultural sector ${ }^{\mathrm{d}}$ & $15.54 \%$ & $8.78 * * *$ & $13.7 \%$ & $5.01 * * *$ & $29.03 \%$ & $10.34 * * *$ \\
\hline Industrial sector ${ }^{\mathrm{d}}$ & $13.08 \%$ & $9.76^{* * *}$ & $5.73 \%$ & $4.03 * * *$ & $24.16 \%$ & $7.64 * * *$ \\
\hline Services sector ${ }^{\mathrm{d}}$ & $19.48 \%$ & $15.48 * * *$ & $15.46 \%$ & $11.66 * * *$ & $19.64 \%$ & $7.78 * * *$ \\
\hline No employees ${ }^{\mathrm{e}}$ & & & & & $-20.62 \%$ & $-8.19 * * *$ \\
\hline Micro firm (1-4 employees $)^{\mathrm{e}}$ & & & $0.96 \%$ & 0.77 & $-7.35 \%$ & $-2.98 * * *$ \\
\hline Small firm (5-19 employees) ${ }^{\mathrm{e}}$ & & & $2.63 \%$ & $2.7 * * *$ & & \\
\hline Medium-sized firm (20-99 employees) ${ }^{\mathrm{e}}$ & & & $1.05 \%$ & 0.78 & & \\
\hline Intermediate $^{\mathrm{f}}$ & & & $18.58 \%$ & $17.35 * * *$ & & \\
\hline Supervisory $^{\mathrm{f}}$ & & & $20.87 \%$ & $14.64 * * *$ & & \\
\hline Indefinite contract & & & $64.42 \%$ & $75.18 * * *$ & & \\
\hline Hours of work & $0.4 \%$ & $3.29 * * *$ & $-1.04 \%$ & $-5.86 * * *$ & $1.14 \%$ & $5.2 * * *$ \\
\hline Hours of work (squared) & $-0.0002 \%$ & -0.15 & $0.0115 \%$ & $5.71 * * *$ & $-0.0046 \%$ & $-2.31 * *$ \\
\hline Recent spell(s) as unemployed & $-22.71 \%$ & $-28.2 * * *$ & $-14.23 \%$ & $-15.69 * * *$ & $-22.79 \%$ & $-12.79 * * *$ \\
\hline Considers herself better skilled & $-3.56 \%$ & $-5.25 * * *$ & $-3.61 \%$ & $-4.66 * * *$ & $-6.08 \%$ & $-4.48 * * *$ \\
\hline \multicolumn{7}{|l|}{ Incomes } \\
\hline Income situation (1-5) & $6.66 \%$ & $18.6^{* * *}$ & $6.34 \%$ & $15.58 * * *$ & $9.98 \%$ & $12.14 * * *$ \\
\hline Ends meet (1-6) & $11.72 \%$ & $35.11 * * *$ & $7.92 \%$ & $20.78 * * *$ & $19.49 \%$ & $27.29 * * *$ \\
\hline Annual earnings $t-1\left({ }^{\prime} 000\right)$ & $0.87 \%$ & $16.57 * * *$ & $0.71 \%$ & $10.1 * * *$ & $0.35 \%$ & $5.65 * * *$ \\
\hline \multicolumn{7}{|l|}{ Business cycle } \\
\hline Unemployment rate $(\%)$ & $-1.8 \%$ & $-12.13 * * *$ & $-1.9 \%$ & $-10.97 * * *$ & $-1.02 \%$ & $-3.19 * * *$ \\
\hline \multicolumn{7}{|l|}{ Country } \\
\hline Austria $^{\mathrm{g}}$ & $25.76 \%$ & $10.76 * * *$ & $2.06 \%$ & 0.78 & $42.91 \%$ & $7.02 * * *$ \\
\hline Belgium $^{\mathrm{g}}$ & $-10.86 \%$ & $-5.09 * * *$ & $-26 \%$ & $-11.83 * * *$ & $-15.47 \%$ & $-3 * * *$ \\
\hline Denmark $^{\mathrm{g}}$ & $15.2 \%$ & $6.06 * * *$ & $-4.38 \%$ & $-1.66^{*}$ & $44.71 \%$ & $5.71 * * *$ \\
\hline Finland $^{\mathrm{g}}$ & $3.27 \%$ & $1.89 *$ & $-6.53 \%$ & $-3.32 * * *$ & $-5.66 \%$ & -1.57 \\
\hline France $^{\mathrm{g}}$ & $-25.73 \%$ & $-15.7 * * *$ & $-43.84 \%$ & $-28.38 * * *$ & $-30.24 \%$ & $-6.19 * * *$ \\
\hline
\end{tabular}


Table 4 continued

\begin{tabular}{|c|c|c|c|c|c|c|}
\hline Variables & $\begin{array}{l}\text { Marginal } \\
\text { effects }(\%)\end{array}$ & $t$ statistics & $\begin{array}{l}\text { Marginal } \\
\text { effects }(\%)\end{array}$ & $t$ statistics & $\begin{array}{l}\text { Marginal } \\
\text { effects }(\%)\end{array}$ & $t$ statistics \\
\hline Germany $^{\mathrm{g}}$ & $-25.14 \%$ & $-13.16^{* * *}$ & $-39.13 \%$ & $-20.57 * * *$ & $-15.12 \%$ & $-2.7 * * *$ \\
\hline Greece $^{\mathrm{g}}$ & $-50.3 \%$ & $-38.71 * * *$ & $-55.07 \%$ & $-36.31 * * *$ & $-47.73 \%$ & $-18.5^{* * *}$ \\
\hline Ireland $^{\mathrm{g}}$ & $11.89 \%$ & $6.19 * * *$ & $-2.92 \%$ & -1.35 & $17.14 \%$ & $4.14 * * *$ \\
\hline Italy $^{\mathrm{g}}$ & $-25.83 \%$ & $-18.95 * * *$ & $-47.2 \%$ & $-35.73 * * *$ & $-11.94 \%$ & $-4.09 * * *$ \\
\hline Luxembourg $^{\mathrm{g}}$ & $-9.27 \%$ & $-2.39 * *$ & $-23.38 \%$ & $-5.86 * * *$ & $-25.37 \%$ & $-2.85 * * *$ \\
\hline Netherlands ${ }^{\mathrm{g}}$ & $1.89 \%$ & 0.84 & $-15.4 \%$ & $-6.49 * * *$ & $9.79 \%$ & 1.5 \\
\hline Portugal $^{\mathrm{g}}$ & $-60.56 \%$ & $-40.16^{* * *}$ & $-74.22 \%$ & $-49.79 * * *$ & $-50.39 \%$ & $-14.93 * * *$ \\
\hline United Kingdom ${ }^{\mathrm{g}}$ & $-22.26 \%$ & $-9.85 * * *$ & $-37.74 \%$ & $-15.98 * * *$ & $-15.85 \%$ & $-3.33 * * *$ \\
\hline Log pseudolikelihood & \multicolumn{2}{|c|}{$-203,212.6$} & \multicolumn{2}{|c|}{$-142,042.8$} & \multicolumn{2}{|c|}{$-54,810.6$} \\
\hline
\end{tabular}

* Significant at $10 \%$ level, $* *$ significant at $5 \%$ level, *** significant at $1 \%$ level

Reference category: ${ }^{\text {a }}$ paid employed; ${ }^{\mathrm{b}}$ non-cohabiting individuals; ${ }^{\mathrm{c}}$ no education or primary education; ${ }^{\mathrm{d}}$ construction sector; ${ }^{\mathrm{e}}$ for paid employees, the reference category is large firm ( $>99$ employees); for self-employed the reference category is small, mediumsized, and large firms ( $>4$ employees); ${ }^{\mathrm{f}}$ non-supervisory; ${ }^{\mathrm{g}}$ Spain

For brevity and focus, only the effects of the explanatory variables on the probability that individuals are satisfied with their job (job satisfaction equals 3) are presented in bold

for self-employed individuals, the probability of being satisfied with job security decreases by $9 \%$, which supports the need to run separate analyses for the selfemployed and employees. Our discussion of these independent estimations is reported below.

With respect to demographic characteristics, females (both the self-employed and employees) are significantly more likely to be satisfied in terms of job security than men. Also, both middle-aged employees and the self-employed are less likely to be satisfied in terms of job security, reaching the lower probability of being satisfied at the age of 43 years. Cohabiting is positively related to satisfaction in terms of job security for paid employees, while it does not seem to have an impact on satisfaction with job security for selfemployed individuals. The findings also illustrate that for both the self-employed and employees, the number of children under 14 years of age does not seem to be related to satisfaction in terms of job security.

Educational attainment does not matter in determining job satisfaction with the type of work for the self-employed. However, we find that those employees with university studies (as compared to those who received only primary education or no schooling) are less likely to be satisfied in terms of job security.

Regarding employment characteristics, workers in the construction sector are less likely to be satisfied with their jobs in terms of job security than workers in any other industry. Furthermore, those employees working in small firms (5-19 employees) are more likely to be satisfied in terms of job security than those in firms of a different size. Additionally, selfemployed individuals with no employees (ownaccount workers) and self-employed individuals of firms with fewer than four employees are less likely to be satisfied in terms of job security than self-employed individuals of larger firms. Also, both having a supervisory and an intermediate job status (as compared to having a non-supervisory job position) increases the probability of being satisfied in terms of job security for employees. Having an indefinite contract is the strongest predictor of satisfaction with job security for employees, with the probability of being satisfied with job security increasing by approximately $64 \%$ for paid employees with an indefinite contract. The job satisfaction of self-employed individuals in terms of job security increases with longer working hours (at a decreasing rate); the reverse is true for paid employees. Furthermore, those who feel that they have the skills or qualifications to do a more demanding job than they currently do are less likely to be satisfied in terms of job security. The same applies to those who have been recently unemployed.

Regarding income, higher relative earnings, a household in which ends are met, and individual work income are positively related to job security. This is true for both employees and self-employed individuals. 
With regard to the impact of the state of the various national economies, it appears that a country's unemployment rate has a negative association with job satisfaction in terms of job security.

Finally, with respect to the existence of countryspecific effects (and using Spain as the reference category), again only minor differences are detected between paid-employed and self-employed workers. Overall, we find that workers in Austria, Denmark, Ireland, and Finland are more likely to be satisfied with their jobs in terms of job security than workers from other countries within the EU-15. The reverse is true for workers from Portugal, Greece, Italy, France, Germany, and the UK.

\section{Conclusion and discussion}

In this study, a large European dataset is used to analyze determinants of job satisfaction, distinguishing between self-employed individuals and paid employees. The main finding is that the self-employed report significantly higher levels of satisfaction with the type of work they do, while paid employees report significantly higher levels of satisfaction in terms of job security, even when a large number of individual and job-related characteristics are controlled for.

That self-employed individuals are more likely than paid employees to be satisfied with the type of work is probably related to the independence and flexibility that the self-employed enjoy as they are not working for a boss. Self-employment has advantages in providing autonomy as compared to paid employment. Self-employed individuals are in charge and therefore capable of (re)defining their work, suggesting that introducing entrepreneurial aspects (i.e., autonomy, independence, etc.) to paid employed jobs may help to increase the job satisfaction of paid employees with their respective type of work. Indeed, this inference seems to be in line with our result that employees with supervisory positions are more satisfied. Even though self-employed individuals indeed often have substantial freedom in creating and shaping their type of work, we can not rule out the possibility that people who tend to be enthusiastic about their type of work are those who self-select into self-employment. However, other factors may also be at play here. Self-employed who have been pushed into self-employment because they have no alternative employment options, for example, may simply be more satisfied as a result of lower expectations-for instance, because they had no jobs or worse jobs in the past.

The finding that self-employed have a lower probability than employees to be satisfied with job security probably follows, as we argued before, from the reality that self-employed, on average, have more limited employment protection than employees and that for the self-employed individual, the risk to fail is higher than the risk that an employee becomes unemployed. Another factor that possibly plays a role in explaining the observed differences in the assessment of job security between the self-employed and employees is that it may be more difficult for selfemployed individuals to predict the extent of job security that they will derive from their own business than it is for employees who are working under a written contract. Thus, while job security circumstances are rather well defined for employeesmeaning that they more or less know what to expect beforehand-it is very well possible that the expectations that the self-employed have in advance about the security that they will get from their own business deviate from their actual job security. The selfemployed, for example, may obtain security from the belief that they can shape their own future, which could result in positive expectations about their ability to (re)define their business to meet threats and to ensure survival (Hundley 2001). When such positive prior expectations are not met in practice, the selfemployed's evaluation of their job security could be negatively affected as a result of the substantial gap between positive prior expectations and the actual situation. Thus, possibly employees are more likely to be satisfied in terms of job security than self-employed because they face a lower gap between expected and actual job security. The ability to predict the extent of job security beforehand is further complicated by the fact that job security is also likely to be more variable for self-employed individuals as it may differ substantially from 1 year to another depending on the specific circumstances and challenges that they encounter with their business.

Our findings underline the importance of education, especially among the self-employed, for increasing one's opportunities for finding an interesting job in terms of type of work. Education, however, appears not to be a determining factor for satisfaction with job security among the self-employed, apparently 
suggesting that having a higher level of education does not help reduce the (perceived) risk of business failure. Furthermore, among employees, those having attended university are even less likely to be satisfied in terms of job security than those who have only primary education or no education. One possible explanation is that employees with university studies have more demanding jobs and have to meet higher expectations, and thus keeping one's job is more challenging.

Looking at firm size, it appears that employees who work in micro, small, and medium-sized firms are more likely to be satisfied with the type of work they do than those working in larger firms. This may imply that employees in smaller firms have more freedom and independence in shaping the type of work they do than those in larger firms. For the self-employed, those who have five or more employees are more likely to be satisfied with job security than those who have no employees or fewer than five employees. This result may indicate that self-employed individuals associate having at least some employees with better survival and growth prospects of the business, which in turn positively affects their perception of job security.

One distinguishing feature between self-employment and paid employment is that self-employment provides for greater skill utilization (Hundley 2001). Previous results for Portugal provide evidence that job satisfaction with type of work and job security is adversely affected by perceived skill underutilization (Allen and van der Velden 2001; Vieira 2005). With respect to satisfaction with type of work, however, our results do not indicate an adverse impact of skill mismatches among the group of self-employed individuals. This indicates that even when self-employed individuals feel they have the skills to do a more demanding job, which potentially might reduce job satisfaction, the advantages of self-employment may compensate for such a negative effect.

A consistent finding is that individuals with better financial positions (both the self-employed and employees) are more likely to be satisfied with their type of work as well as with job security. For employees, this might mean that better paying jobs are also the ones that provide satisfactory work content. Furthermore, with respect to job security, it could mean that the better paying job is also the more secure job and/or that having a better financial position makes you less worried about job security as you are able to take some financial losses in case you lose your job. For self-employed individuals, the positive relationship between financial position and the two types of job satisfaction suggests that having a better financial position improves the ability of these individuals to shape the content of the work they do (i.e., they can be a bit more critical in accepting or rejecting assignments) as well as their ability to survive and perform well within the framework of their business.

Self-employed individuals are distinguished by the effort they put into their work. We even find that among the self-employed, working more hours is associated with being more satisfied with the type of work and job security. For both types of job satisfaction, however, we found that when paid employed individuals work longer hours they are less likely to be satisfied. Possibly working longer hours is more of a free choice for selfemployed individuals than for employees and results in positive returns or benefits for the self-employed.

Another consistent finding among both self-employed individuals and employees is that those who have experienced recent spells of unemployment tend to be less satisfied with their jobs both in terms of type of work and job security. ${ }^{13}$ It is likely that these individuals have more limited choices for finding satisfying jobs and are also more aware of the risks of losing one's job. Furthermore, this negative effect of previous spells of unemployment is particularly strong in the case of satisfaction with job security among self-employed individuals, which suggests these individuals are particularly insecure about their chances of survival. Governments may want to consider this when designing their policy initiatives to encourage the unemployed to enter into self-employment, which are present in many countries (Kluve and Card 2007; Shutt and Sutherland 2003).

One final result that we would like to highlight is that national unemployment rates relate positively to job satisfaction in terms of type of work, while these relate negatively to satisfaction in terms of job security. The first finding may reflect that, in the case of high unemployment rates, people are simply happy not to be unemployed and therefore report higher levels of satisfaction with the type of work they do.

\footnotetext{
$\overline{13}$ Previous research reports that those entrepreneurs with previous unemployment experience are less likely to survive as entrepreneurs (Millán et al. 2011a; Van Praag, 2003). Similarly, other studies indicate that push entrepreneurs are less successful, both in terms of venture success (sales per employee) and personal income than pull entrepreneurs (Amit and Muller 1995).
} 
The latter finding implies that when unemployment rates are higher, job conditions may worsen and people may also be more aware of the risk of losing their job and hence report lower levels of satisfaction with their job in terms of job security.

Although the results of our study highlight the importance of considering different aspects of job satisfaction (type of work and job security) when comparing self-employed individuals and paid employees, we acknowledge that there a number of limitations to our study. For example, we rely on self-reported measures of job satisfaction derived from answers to subjective questions that may be perceived differently by people in different countries (Kristensen and Johansson 2008; Lévy-Garboua and Montmarquette 2004). Blanchflower and Freeman (1994) stress that people in one country may "scale" responses differently than those in another. For instance, Americans may be relatively optimistic, with an "everything will work out" mentality that leads people with the same true satisfaction on some objective scale to respond more positively to a "Are you satisfied with your job?" question than the British who tend to be more reserved. Furthermore, the current analysis does not allow us to isolate directions of causality. Lastly, we only focus on entrepreneurship in terms of self-employment and do not consider other approaches that define entrepreneurs as a heterogeneous group such as: (1) innovative against imitative entrepreneurs (Schumpeter 1912), (2) opportunity against necessity entrepreneurs (Reynolds et al. 2002), (3) the distinction between several engagement levels of the entrepreneurial process (Grilo and Thurik 2008; Van der Zwan et al. 2010), and (4) the distinction between selfemployed with employees and the own-account workers (Earle and Sakova 2000; Millán et al. 2011b).

Lastly, we would like to highlight a number of avenues for future research, such as whether or not higher levels of job satisfaction are associated with higher levels of economic utility over time.
Furthermore, future research could help to establish whether different aspects of job satisfaction affect the occupational choice between self-employment and paid employment. Previous studies have provided evidence of job dissatisfaction as a reason for new venture creation (Brockhaus 1980; Cromie and Hayes 1991; Hisrich and Brush 1986). Finally, it would be interesting to consider the influence of various labor market institutional factors, such as employment protection legislation, unionism, and active labor market policies, on several types of job satisfaction.

Acknowledgments The authors would particularly like to thank Andrew Burke, Gavin Reid, Concepción Román and Juan Sanchis for their helpful comments and suggestions. The work also has benefited from comments from participants at the Interdisciplinary European Conference on Entrepreneurship Research (Lisbon, 2009), the XI World Economy Meeting (Huelva, 2009), the XII Applied Economics Meeting (Madrid, 2009), the Babson College Entrepreneurship Research Conference (Boston, 2009), the RENT XXIII-Research in Entrepreneurship and Small Business (Budapest, 2009) and a Erasmus-EIM-Panteia Entrepreneurship Lecture (Zoetermeer, 2010). The paper has been written in the framework of the research program SCALES carried out by EIM Business and Policy Research and financed by the Dutch Ministry of Economic Affairs, Agriculture and Innovation. At the time of writing the paper, José María Millán was completing a research stay at the Erasmus University Rotterdam, which was funded with a postdoctoral fellowship from the Spanish Ministry of Education (Programa Nacional de Movilidad de Recursos Humanos, Plan Nacional de I+D+i 2008-2011). The usual disclaimer applies.

Open Access This article is distributed under the terms of the Creative Commons Attribution Noncommercial License which permits any noncommercial use, distribution, and reproduction in any medium, provided the original author(s) and source are credited.

\section{Appendix}

See Table 5 .

Table 5 Description of variables

Dependent variables
Job satisfaction with type of work

Job satisfaction with job security
Dependent variable varies from 1 to 3 showing a scale of job satisfaction with present job in terms of type of work. Thus, this variable equals 1 for individuals who are not satisfied with their present job and 3 for satisfied individuals.

Dependent variable varies from 1 to 3 showing a scale of job satisfaction with present job in terms of job security. Thus, this variable equals 1 for individuals who are not satisfied with their present job and 3 for satisfied individuals. 
Table 5 continued

\begin{tabular}{|c|c|}
\hline \multicolumn{2}{|l|}{ Explanatory variables } \\
\hline \multicolumn{2}{|l|}{ Self-employment } \\
\hline Self-employed & Dummy equals 1 for self-employed individuals. \\
\hline \multicolumn{2}{|l|}{ Demographic characteristics } \\
\hline Female & Dummy equals 1 for females. \\
\hline Age & Age reported by the individual, ranging from 18 to 65 years. \\
\hline Cohabiting & Dummy equals 1 for cohabiting individuals. \\
\hline \multicolumn{2}{|l|}{ Education } \\
\hline No education/primary education & $\begin{array}{l}\text { Dummy equals } 1 \text { for individuals with less than second stage of secondary } \\
\text { education (ISCED 0-2). }\end{array}$ \\
\hline Secondary education & $\begin{array}{l}\text { Dummy equals } 1 \text { for individuals with second stage of secondary level education } \\
\text { (ISCED 3). }\end{array}$ \\
\hline University studies & $\begin{array}{l}\text { Dummy equals } 1 \text { for individuals with recognized third level education (ISCED } \\
5-7 \text { ). }\end{array}$ \\
\hline \multicolumn{2}{|l|}{ Employment characteristics } \\
\hline Agricultural sector & $\begin{array}{l}\text { Dummy equals } 1 \text { for individuals whose codes of main activity of the local unit of } \\
\text { the business is A (Agriculture, Hunting and Forestry) and B (Fishing), by the } \\
\text { "Nomenclature of Economic Activities" (NACE-93). }\end{array}$ \\
\hline Construction sector & $\begin{array}{l}\text { Dummy equals } 1 \text { for individuals whose codes of main activity of the local unit of } \\
\text { the business is F (construction), by the "Nomenclature of Economic } \\
\text { Activities" (NACE-93). }\end{array}$ \\
\hline Industrial sector & $\begin{array}{l}\text { Dummy equals } 1 \text { for individuals whose codes of main activity of the local unit of } \\
\text { the business are C (mining and quarrying), D (manufactures) and E (electricity, } \\
\text { gas and water supply), by the "Nomenclature of Economic Activities" } \\
\text { (NACE-93). }\end{array}$ \\
\hline Services sector & $\begin{array}{l}\text { Dummy equals } 1 \text { for individuals whose codes of main activity of the local unit of } \\
\text { the business are G (wholesale and retail trade; repair of motor vehicles, } \\
\text { motorcycles and personal/household goods), H (hotels and restaurants) and I } \\
\text { (transport, storage and communication), J (Financial intermediation) and K } \\
\text { (real estate, renting and business activities), L (public administration and } \\
\text { defense; compulsory social security), M (education), N (health and social } \\
\text { work) and O-Q (other community, social and personal service activities; } \\
\text { private households with employed persons; extra-territorial organizations and } \\
\text { bodies), by the "Nomenclature of Economic Activities" (NACE-93). }\end{array}$ \\
\hline No employees & Dummy equals 1 for own-account workers individuals (0 employees). \\
\hline Micro firm (1-4 employees) & Dummy equals 1 for individuals working in very small firms (1-4 employees). \\
\hline Small firm (5-19 employees) & Dummy equals 1 for individuals working in small firms (5-19 employees). \\
\hline Medium-sized firm (20-99 employees) & $\begin{array}{l}\text { Dummy equals } 1 \text { for individuals working in medium-sized firms (20-99 } \\
\text { employees). }\end{array}$ \\
\hline Large firm (>99 employees) & Dummy equals 1 for individuals working in large firms ( $>99$ employees). \\
\hline Non-supervisory & Dummy equals 1 for individuals whose job status is non-supervisory. \\
\hline Intermediate & Dummy equals 1 for individuals whose job status is intermediate. \\
\hline Supervisory & Dummy equals 1 for individuals whose job status is supervisory. \\
\hline Hours of work & Hours of work per week. \\
\hline Indefinite contract & Dummy equals 1 for workers with indefinite contract. \\
\hline Recent spell(s) as unemployed & $\begin{array}{l}\text { Dummy equals } 1 \text { for individuals with previous spell(s) as unemployed after } \\
1989 \text {. }\end{array}$ \\
\hline Considers herself better skilled & $\begin{array}{l}\text { Dummy equals } 1 \text { for individuals who feel they have the skills or qualifications to } \\
\text { do a more demanding job than the one they have. }\end{array}$ \\
\hline
\end{tabular}


Table 5 continued

Incomes

Income situation

Ends meet

Annual earnings $t-1\left({ }^{\circ} 000\right)$

Business cycle

Unemployment rate

Country dummies

Dummies equal 1 for individuals living in the named country, and 0 otherwise. The following countries are included: Austria, Belgium, Denmark, Finland, France, Germany, Greece, Ireland, Italy, Luxembourg, Netherlands, Portugal, Spain, and United Kingdom.

\section{References}

Acemoglu, D. (1995). Reward structures and the allocation of talent. European Economic Review, 39(1), 17-33.

Akerlof, G. A., Rose, A. K., \& Yellen, J. L. (1988). Job switching and job satisfaction in the U.S. labor market. Brookings Papers on Economic Activity, 2, 495-582.

Allen, J., \& van der Velden, R. (2001). Educational mismatches versus skill mismatches: Effects on wages, job satisfaction and on the job search. Oxford Economic Papers, 53(3), 434-452.

Amit, R., \& Muller, E. (1995). "Push" and "pull" entrepreneurship. Journal of Small Business and Entrepreneurship, 12(4), 64-80.

Benz, M., \& Frey, B. S. (2004). Being independent raises happiness at work. Swedish Economic Policy Review, 11, 95-134.

Benz, M., \& Frey, B. S. (2008). Being independent is a great thing: Subjective evaluations of self-employment and hierarchy. Economica, 75(298), 362-383.

Besley, T., \& Ghatak, M. (2005). Competition and incentives with motivated agents. American Economic Review, 95(3), 616-636.

Bianchi, M. (2011). Financial development, entrepreneurship and job satisfaction. Review of Economics and Statistics (in press). doi:10.1162/REST_a_00156.

Blanchflower, D. G. (2000). Self-employment in OECD countries. Labour Economics, 7, 471-505.

Blanchflower, D. G. (2004). Self-employment: More may not be better. Swedish Economic Policy Review, 11(2), 15-74.

Blanchflower, D. G., \& Freeman, R. B. (1994). Did the Thatcher reforms change British labour market performance? In R. Barrell (Ed.), The UK labour market. Comparative aspects and institutional developments. Cambridge: Cambridge University Press.
Blanchflower, D. G., \& Oswald, A. J. (1998). What makes an entrepreneur? Journal of Labor Economics, 16(1), 26-60.

Blanchflower, D. G., Oswald, A. J., \& Stutzer, A. (2001). Latent entrepreneurship across nations. European Economic Review, 45(4-6), 680-691.

Borjas, G. J. (1979). Job satisfaction, wages and unions. Journal of Human Resources, 14, 21-40.

Bradley, D. E., \& Roberts, J. A. (2004). Self-employment and job satisfaction: Investigating the role of self-efficacy, depression and seniority. Journal of Small Business Management, 42(1), 37-58.

Brockhaus, R. H. (1980). The effect of job dissatisfaction on the decision to start a business. Journal of Small Business Management, 18, 37-43.

Brown, S. P., \& Lam, S. K. (2008). A meta-analysis of relationships linking employee satisfaction to customer responses. Journal of Retailing, 84(3), 243-255.

Clark, A. E. (1996). Job satisfaction in Britain. British Journal of Industrial Relations, 34(2), 189-217.

Clark, A. E. (1997). Job satisfaction and gender: Why are women so happy at work? Labour Economics, 4(4), 341-372.

Clark, A. E. (2001). What really matters in a job? Hedonic measurement using quit data. Labour Economics, 8, 223-242.

Clark, A. E., Georgellis, Y., \& Sanfey, P. (1998). Job satisfaction, wage changes and quits: Evidence from Germany. Research in Labor Economics, 17, 95-121.

Clark, A. E., \& Oswald, A. J. (1994). Unhappiness and unemployment. Economic Journal, 104, 648-659.

Clark, A. E., \& Oswald, A. J. (1996). Satisfaction and comparison income. Journal of Public Economics, 61(3), 359-381.

Cromie, S., \& Hayes, J. (1991). Business ownership as a means of overcoming job dissatisfaction. Personnel Review, 20, 19-24. 
Delfgaauw, J., \& Dur, R. (2008). Incentives and workers motivation in the public sector. Economic Journal, 118, 171-191.

Delfgaauw, J., \& Dur, R. (2009). From public monopsony to competitive market: More efficiency but higher prices. Oxford Economic Papers, 61(3), 586-602.

de Muñoz Bustillo Llorente, R., \& Macías, E. F. (2005). Job satisfaction as an indicator of the quality of work. The Journal of Socio-Economics, 34, 656-673.

Earle, J. S., \& Sakova, Z. (2000). Business start-ups or disguised unemployment? Evidence on the character of selfemployment from transition economies. Labour Economics, 7, 575-601.

European Commission. (2004). Second career. Overcoming the obstacles faced by dependent employees who want to become self-employed and/or start their own business. Brussels: European Commission.

Eurostat. (2004). Business demography in Europe. Results for 10 Member States and Norway. Luxembourg: Eurostat.

Evans, D. S., \& Jovanovic, B. (1989). An estimated model of entrepreneurial choice under liquidity constraints. Journal of Political Economy, 97(4), 808-827.

Francois, P. (2000). Public service motivation as an argument for government provision. Journal of Public Economics, 78(3), 275-299.

Freeman, R. B. (1978). Job satisfaction as an economic variable. American Economic Review, 68, 135-141.

Georgellis, Y., Sessions, J. G., \& Tsitsianis, N. (2007). Pecuniary and non-pecuniary aspects of self-employment survival. Quarterly Review of Economics and Finance, 47(1), 94-112.

Glazer, A. (2004). Motivating devoted workers. International Journal of Industrial Organization, 22(3), 427-440.

Green, F., \& Tsisianis, N. (2005). An investigation of national trends in job satisfaction in Britain and Germany. British Journal of Industrial Relations, 43(3), 401-429.

Grilo, I., \& Thurik, A. R. (2008). Determinants of entrepreneurial engagement levels in Europe and the US. Industrial and Corporate Change, 17(6), 1113-1145.

Hamermesh, D. S. (1977). Economic aspects of job satisfaction. In O. Ashenfelter \& W. Oates (Eds.), Essays in labor market analysis. New York: Wiley.

Hamilton, B. H. (2000). Does entrepreneurship pay? An empirical analysis of the returns to self-employment. Journal of Political Economy, 108(3), 604-631.

Hisrich, R. D., \& Brush, C. (1986). Characteristics of the minority entrepreneur. Journal of Small Business Management, 24, 1-8.

Hundley, G. (2001). Why and when are the self-employed more satisfied with their work? Industrial Relations, 40(2), 293-316.

Hyytinen, A. \& Ruuskanen, O-P. (2006) What makes an entrepreneur independent? Evidence from time use survey. Discussion paper no. 1029. Helsinki: The Research Institute of the Finnish Economy.

Kihlstrom, R. E., \& Laffont, J.-J. (1979). A general equilibrium entrepreneurial theory of firm formation based on risk aversion. Journal of Political Economy, 87(4), 719-748.

Kluve, J., \& Card, D. (Eds.). (2007). Active labor market policies in Europe: Performance and perspectives. Berlin: Springer Verlag.
Koys, D. J. (2001). The effects of employee satisfaction, organizational citizenship behavior, and turnover on organizational effectiveness: A unit-level, longitudinal study. Personnel Psychology, 54(1), 101-114.

Kristensen, N., \& Johansson, E. (2008). New evidence on crosscountry differences in job satisfaction using anchoring vignettes. Labour Economics, 15, 96-117.

Lévy-Garboua, L., \& Montmarquette, C. (2004). Reported job satisfaction: What does it mean? Journal of Socio-Economics, 33, 135-151.

Lusch, R. F., \& Serpkenci, R. R. (1990). Personal differences, job tension, job outcomes, and store. Journal of Marketing, 54(1), 85-101.

Meng, R. (1990). The relationship between unions and job satisfaction. Applied Economics, 22, 1635-1648.

Millán, J. M., Congregado, E., \& Román, C. (2011a). Determinants of self-employment survival in Europe. Small Business Economics (in press). doi:10.1007/s11187-010-9260-0.

Millán, J. M., Congregado, E., \& Román, C. (2011b). Entrepreneurship persistence with and without personnel: The role of human capital and previous unemployment. International Entrepreneurship and Management Journal (in press). doi:10.1007/s11365-011-0184-1.

Noorderhaven, N., Thurik, A. R., Wennekers, A. R. M., \& Van Stel, A. J. (2004). The role of dissatisfaction and per capita income in explaining self-employment across 15 European countries. Entrepreneurship Theory and Practice, 28(5), 447-466.

Origo, F., \& Pagini, L. (2009). Flexicurity and job satisfaction in Europe: The importance of perceived and actual job satisfaction for well being at work. Labour Economics, 16, 547-555.

Ostroff, C. (1992). The relationship between satisfaction, attitudes, and performance: An organizational level analysis. Journal of Applied Psychology, 77(6), 963-974.

Parasuraman, S., \& Simmers, C. A. (2001). Type of employment, work-family conflict and well-being: A comparative study. Journal of Organizational Behavior, 22(5), 551-568.

Parker, S. C. (2009). The economics of entrepreneurship. Cambridge: Cambridge University Press.

Peracchi, F. (2002). The European community household panel: A review. Empirical Economics, 27, 63-90.

Prendergast, C. (2007). The motivation and bias of bureaucrats. American Economic Review, 97(1), 180-196.

Reynolds, P., Camp, S. M., Bygrave, W. D., Autio, E., \& Hay, M. (2002). Global entrepreneurship monitor 2001 executive report. London: Babson College and London Business School.

Rogers, J. D., Clow, K. E., \& Kash, T. J. (1994). Increasing job satisfaction of service personnel. Journal of Service Management, 8(1), 14-26.

Ryan, A. M., Schmit, M. J., \& Johnson, R. (1996). Attitudes and effectiveness: Examining relations at an organizational level. Personnel Psychology, 49(4), 853-882.

Schumpeter, J. A. (1912). Theorie der Wirtschaftlichen Entwicklung ("The theory of economic development"). Leipzig: Dunker \& Humblot; translated by Dedvers Opie. Cambridge, MA: Harvard University Press, 1934.

Shutt, J., \& Sutherland, J. (2003). Encouraging the transition into self-employment. Regional Studies, 37(1), 97-103. 
Sousa-Poza, A., \& Sousa-Poza, A. (2000). Well-being at work: A cross-national analysis of the levels and determinants of job satisfaction. Journal of Socio-Economics, 29(6), 517-538.

Taylor, M. P. (1996). Earnings, independence or unemployment: Why become self-employed? Oxford Bulletin of Economics and Statistics, 58(2), 253-266.

Taylor, M. P. (1999). Survival of the fittest? An analysis of selfemployment duration in Britain. The Economic Journal, 109, 140-155.

Van der Zwan, P., Thurik, A. R., \& Grilo, I. (2010). The entrepreneurial ladder and its determinants. Applied Economics, 42(17), 2183-2191.

Van Praag, C. M. (1999). Some classic views on entrepreneurship. De Economist, 147(3), 311-335.

Van Praag, C. M. (2003). Business survival and success of young small business owners. Small Business Economics, 21, 1-17.
Van Praag, C. M., \& Versloot, P. H. (2007). What is the value of entrepreneurship? A review of recent research. Small Business Economics, 29, 351-382.

Verheul, I., Wennekers, A. R. M., Audretsch, D. B., \& Thurik, A. R. (2002). An eclectic theory of entrepreneurship, In D. B. Audretsch, A. R. Thurik, I. Verheul, \& A. R. M. Wennekers (Eds.), Entrepreneurship: Determinants and policy in a European-US comparison. Boston: Kluwer Academic Publishers, pp 11-81.

Vieira, J. A. C. (2005). Skill mismatches and job satisfaction. Economics Letters, 89, 39-47.

Vroom, V. (1964). Work and motivation. New York: Wiley.

Williams, R. (2006). Generalized ordered logit/partial proportional odds models for ordinal dependent variables. Stata Journal, 6(1), 58-82. 